\title{
SOME ADDITIONS TO THE DIPTERAN FAUNA OF NEW ENGLAND.
}

\author{
By Charless W. Johnson. \\ Boston Society of Natural History. \\ Pogonosoma dorsatum Say.
}

A specimen of this species was obtained by Mr. F. A. Sherriff at the base of Mt. Washington near Fabyan, N. H., July 7, 1910. I am not aware that the species has been collected east of the Rocky Mountains since it was described by Say from "near Philadelphia." It has been recorded from Washington (Williston) and Idaho (Aldrich). Specimens are in the writer's collection from Bear Creek Cañon, Colo., June 8, 1897 (Oslar), and Estes Park, Colo., July, 1892 (Snow).

Pogonosoma melanoptera Wiedemann.

In the collection of the American Museum of Natural History is a specimen of this species collected by Prof. W. M. Wheeler at Woods Hole, Mass., July 18. The distribution of the species would indicate an austral form. It has been recorded from Florida (Williston), South Carolina (Schiner), Maryland (Mus. Comp. Zool.) and New Brunswick, N. J. (Dr. J. B. Smith). Specimens are in the writer's collection from Alabama, Pendleton, N. C., June 7, 1895, and Philadelphia, Pa., July 5, 1898.

\section{Ceraturgus nigripes Williston.}

One specimen collected on the side of Mt. Equinox, near Manchester, Vt., June 5, 1910, at an elevation of about 2,000 feet.

The specimen agrees with the description of $C$. nigripes, except in two minor details. The wings are not "pure hyaline," but grayish with a distinct brownish tinge along costa and the outer half. The legs of $C$. nigripes are described as "pitchy black, the tibiæ and tarsi fulvous pubescent," while in this specimen the femora only are "pitchy black," the tibiæ and tarsi yellow, all 
the joints of the latter annulated with black, with an apical band of black on the tibiæ. In the closely allied species $C$. cruciatus Say, the color of the legs is extremely variable. There seems therefore to be little doubt but that this represents only an extreme variation of $C$. nigripes although the species has not been recorded north of the Black Mountains, N. C.

Phthiria borealis n. sp.

Black, covered with a dense yellowish gray pollen; the frontal orbits, occiput, humeri, scutellum and a narrow posterior margin on the abdominal segments, dull yellow; antennæ and proboscis black, the latter slightly more than double the length of the head; legs black, tips of the coxæ and femora yellow; halteres light yellow with a brown spot. on the side of the knob. Wings pure hyaline. Length $3.5 \mathrm{~mm}$.

Type $ᄋ$, Fort Kent, Maine, August 7, 1910. Two specimens were also collected by Dr. J. A. Cushman at Little Black River Rapids, Maine, September 13, 1907. This is the most northern representative of the genus thus far discovered in North America.

Phthiria sulphurea Loew.

A specimen of this species from Horse Neck Beach, Mass., collected August 9, by Dr. G. de N. Hough is in the collection of the American Museum of Natural History.

Phthiria coquilletti Johnson.

Two specimens were collected by Dr. J. A. Cushman on Nantucket, Mass., July 4, 1906. They are slightly smaller than the types from southern New Jersey.

Phthiria cyanoceps Johnson.

In addition to the type locality (Cohasset, Mass.) this species has been taken at Barbour's Heights, R. I., September 19, 1908, by Prof. John Barlow.

Chalcomyia aerea Loew.

This interesting species was taken at Auburndale, Mass., May 8, 1905. I have also collected it near Clifton, Delaware County, Pa., May 5, 1895, on an old log in the bright sunlight. 
Brachyopa vacua Osten Sacken.

Cohasset, Mass., June 5, 1904 (Owen Bryant). It has also been taken at North Saugus, Mass.

\section{Brachyopa media Williston.}

A specimen was captured on the summit of Mt. Greylock, Mass., June 15, 1906; on the flowers of the wild cherry. Mr. E. J. Smith also collected a specimen at Sherborn, Mass. A peculiar variation of this species, in which the abdomen is entirely black, was obtained by Mr. E. Daecke at Castle Rock, Delaware County, Pa., May 19, 1901.

\section{Sphegina campanulata Robertson.}

This species seems to be quite generally distributed throughout New England:-Branford, Conn., May 25, 1905 (Rev. H. W. Winkly); Hampton, N. H., June 25, 1908 (S. A. Shaw); Machias, Maine, July 17-22, 1909 (C. W. Johnson).

\section{Xanthogramma tenuis Osburn.}

A single example of this western species was obtained by the writer at Ethan Allen Park, Burlington, Vt., June 24, 1906.

\section{Eumerus strigatus Fallen}

Pipiza strigata Fall., Dipt. Seuc. Syrphici, 61, 8, 1817.

Eumerus grandicornis and funeralis Meigen, Syst. Beschr., III, 208, 1822.

E. lunulatus and planifrons Meigen, Syst. Beschr., III, 209, 1822.

E. ceneus Macq., Soc. Sci. Lille, 1827, p. 269; Hist. Nat. Ins. Dipt. I, p. 528, 1834.

Two specimens of this European species have come under the writer's observation. The first was obtained at Brookline, Mass., June 1909; the second was received from Mr. M. C. Van Duzee who collected it at Buffalo, N. Y., June 3, 1908. The genus has not been recorded from America, but the presence of this species in such widely separated localities seems to preclude the possibility of recent introduction. The above synonomy is that given (in part) in the Katalog der Paläarktischen Dipteren, III, 137. 


\section{Xylota (?) tuberans Williston.}

This interesting species has been collected at a number of places during the past few years: Squam Lake, N. H., June 22, 1907 (Dr. G. M. Allen); Mt. Equinox, Manchester, Vt., June 5, 1910.

\section{Hypoderma bovis De Geer.}

The ox-bot seems to have been unusually prevalent the past season. Mr. Wm. Merrill of West Newbury, Mass., in a letter dated May 17, 1910, says: "I have never seen the ox-bot so numerous; of our eight head of cows every one is affected with from six to over sixty each. Other cows in the neighborhood are also affected." I visited West Newbury, May 27, and saw the cows referred to but obtained only one larva; most of the larvæ having already left the cattle. The larva was apparently full grown, but light brown in color.

During the early part of June while at Manchester, Vt., I found the cattle slightly affected, about half of the cows having from one to four bots. Three larvæ were obtained June 9, one of which was white, about half grown, I should judge, but the swelling was just as large due to the presence of a large amount of pus; the second specimen was a light brown apparently full grown, but like the one from West Newbury failed to pupate; the third was evidently ready to leave the cow, the opening was large and the larva blackish in color. It was placed in damp earth and pupated June 11, the imago emerging June 30. From these observations I am inclined to doubt the statement that "the full-grown larva when escaping from the back is of a grayish-white color."

In comparing the above-mentioned fly with specimens of $H$. lineatum De Villiers, from Texas and Colorado, I find that the species is $\boldsymbol{H}$. bovis, the occurrence of which in North America has been doubted. Whether all of the larvæ referred to belong to this species I cannot say, as both species probably occur in New England. $\boldsymbol{H}$. bovis can be readily distinguished from $\boldsymbol{H}$. lineatum by yellow pile of the thorax extending to the suture, the broader and less conspicuous polished ridges on the thorax, the wings slightly darker, the entirely black metanotum and black tibiæ. It is also noticeably larger and more robust. 
Ceratinostoma ostiorum Haliday.

Scatophaga ostiorum Halid., Curtis Brit. Entom., 405, 1832.

Scatomyza boreale Zett., Ins. Lapp., 721, 4, 1838.

Scatophaga oceana Macq., Ann. Soc. Ent. France, VII, 423, pl. 11, fig. 2, 1838.

Lispa lestremense Bigot, Anna. Soc. Ent. France, IV, (Ser. 6) 292, 1884.

Ceratinostoma maritimum Meade, Ent. Monthly Mag., XXII, 152, 1885.

This European species has not been recorded from North America although it is quite generally distributed along the New England coast. I first received several specimens from Mr. S. A. Shaw, collected at Hampton Beach, N. H., May 24. Mr. Owen Bryant captured a specimen at Cohasset, Mass., September 9, and Dr. C. S. Minot a specimen at Northeast Harbor, Maine, July 4, 1909. On July 25, 1907, the writer obtained a number of specimens at Orr's Island, Maine, on the wet rocks at low tide. A number were also obtained on the rocky shore at Shackford's Head near Eastport, Maine, July 14, 1909.

Mead refers to this genus as occupying an intermediate position between Scatophaga and Cordylura. "It has the elongated horny proboscis with the numerous vibrissæ of the species in the former genus and the sub-cylindrical incurved clubbed male abdomen of those of the latter."

The species can be readily recognized by the following characters: Face white, front dark brown, antennæ and proboscis black, palpi yellow. Thorax, abdomen and legs slate-gray in color, the former having three wide obscure stripes. Tegulæ and halteres yellow. Hairs and bristles noticeably shorter than in most of the Scatophagi. Length $8 \mathrm{~mm}$. The synonomy is that given in the Katalog der Paläarktischen Dipteren, IV, 12.

\section{Scatophaga volucricaput Walker.}

Cordylura volucricaput Walker, List Dipt. Brit. Mus. pt. 4, p. 977, 1849; Aldrich, Cat. N. A. Dipt., p. 566.

Hydromyza volucricaput Slosson, Ent. News, Vol. VI, p. 320, 1895.

Specimens agreeing with the description of this species (which proves to be a Scatophaga) are represented from the following localities: Mt. Washington, N. H., (Mrs. Slosson); Durham, N. H., July 17, 1905 (J. Randall); Buffalo, N. Y., October 25 (M. C. Van Duzee). 


\section{Palloptera similis n. sp.}

Head and antennæ yellow, arista brown, ocellar triangle blackish. Thorax and scutellum shining, reddish yellow, pluræ yellow, opaque. Abdomen shining, yellow, the posterior edges of the segments narrowly and the sides broadly margined with black. Legs and halteres light yellow. Wings with the broad anterior of dark brown, as in P. superba Loew, but the brown at the posterior cross vein is not connected. Length, $6 \mathrm{~mm}$.

One $q$ collected by the writer at Fort Kent, Maine, August 17, 1910. Type in the New England Collection of the Boston Society of Natural History.

This species closely resembles $P$. superba but is readily separated by its shining thorax and abdomen, with the black margins of the segments continuous and not punctate. From $P$. jucunda it is distinguished by its larger size and by the marginal cell being entirely brown.

\section{Palloptera arcuata Fallen.}

Two specimens of this species were collected by Dr. C. S. Minot at Northeast Harbor, Maine, July 1, 1909. It has previously been recorded in America only from the White Mts., N. H. Sapromyza inusta Meigen given as a synonym in Aldrich's Catalogue (p. 582) is a good species and a true Sapromyza. Figure 15, page 80 of Williston's Manual North American Diptera, represents Palloptera superba and not $P$. jucunda Loew.

\section{Ortalidae.}

The following species of this family have been collected in various parts of New England, extending considerably their recorded distribution.

Rivellia brevifasciata Johns., Tuckernuck Isl., Mass., July 21, 1910 (Dr. G. M. Allen).

Rivellia conjuncta Loew, New Haven, Conn., June 8 (Dr. W. E. Britton); Barnstable, Mass., July 4; Woods Hole, Mass., July 24 (C. W. Johnson).

Rivellia quadrifasciata Macq., New Haven, Conn., Aug. 1, Springfield, Mass., July 13 (Dr. Dimmock).

Rivellia pallida Loew, Mt. Greylock, Aug. 8, 1907 (Owen Bryant); Auburndale, Aug. 9, and Plymouth, Mass., July 27 (C. W. Johnson).

Tritoxa incurva Loew, East Hartford, Conn., Aug. 9, 1904 (P. L. Butrick). 
Tephronota canadensis Johns., Eastport, Maine (C. W. Johnson).

Tetanops luridipennis Loew, New Haven, Conn., June 26 (H. L. Vierick).

Euxesta scoriacea Loew, Bourne, Mass., June 17 (P. G. Bolster).

Chaetopsis apicalis Johns., Common along the salt marshes at Edgartown, Chatham, and Cohasset, Mass.

Seoptera colon Loew, Northeast Harbor, Maine, July 16, 1906 (Dr. C. S. Minot).

Stenomyia tenuis Loew, North Haven, Conn., Nantucket, Barnstable and Woburn, Mass. This is now placed in the genus Choetopsis by Hendel (Gen. Ins., Muscaridæ, Ulidinæ, p. 35).

Eumetopia rufipes Macq., New Haven, Conn., July 27, 1904 (P. G. Butrick); Kingston, R. I., June 23, 1905 (Barlow); Now placed in the genus Eumetopiella Hendel 1907.

Tanypeza longimana Fallen.

This species, although not recorded from North America, seems to be quite generally distributed: Algonquin, Ill., June 8, 1895 (Dr. W. A. Nason); Niagara Falls, N. Y., June 28, 1901; Norwich, Vt., July 8, 1908.

\section{Saltella scutellaris Fallen.}

Piophila scutellaris Fall., Heteromyzides, 10, 3, 1820.

Nemopoda ferruginea Desv., Myodaires, 744, 2, 1830.

Saltella nigripes Desv., Myodaires, 747,2, 1830.

Nemopoda scutellata and ruficoxa Macq. Hist. Nat. Dipt., II, 481, 1835.

Saltella pectoralis Zett., Dipt. Scand., IV, 2515, 8, 1847.

A single specimen of this European species was taken by Mr. M. C. Van Duzee at Hamburg, N. Y., June 20, 1909.

Eusiphona mira Coquillett.

Hanover, N. H., July 14-6, 1908. It was found only on the flowers of the cone-flower (Rudbeckia hirta).

\section{Odinia maculata Meigen.}

Milichia maculata Meig., Syst. Beschr., VI, 132, 1830.

Milochia ornata Zett., Ins. Lapp., 787, 1, 1838.

Odinia trinotata Desv., Myodaires, 648, 1, 1830.

Dauphine County, Pa., April 20, 1897 (Dr. D. M. Castle); Cambridge, Mass., June 11, 1908 (Dr. G. M. Allen). 
Odinia picta Loew.

There seems to be no record of the occurrence of this species since it was described from Georgia. A specimen was taken by the writer at Glenside, Pa., June 2, 1895. A second specimen from Branford, Conn., June 23, was collected by Mr. H. L. Viereck.

\section{THE NORTH AMERICAN FORMS OF LASIUS UMBRA- TUS NYLANDER. ${ }^{1}$}

\section{By William Morton Wheeler.}

Like many other ants that are peculiar to the north temperate zone, Lasius umbratus is very widely distributed and presents a number of local subspecies and varieties. In the Old World it ranges from England to Japan, through northern and central Eurasia; in North America from Nova Scotia and the Atlantic States to the Rocky Mountains and will probably be found on the Pacific Coast, at least in the mountains of California or at lower elevations in Washington and Oregon. According to Forel and Emery the species is represented in Europe by four subspecies, namely, the typical umbratus Nyl., mixtus Nyl., affinis Schenk and bicornis Förster. To these Ruzsky has added a fifth, exacutus, from Oriental Russia.. To judge from a female specimen in my collection, the Japanese form is indistinguishable from the typical umbratus. Transitional forms which Forel has called mixto-umbratus occur in Switzerland, and others which Ruzsky has called umbrato-affinis have been taken in eastern Russia. Mayr cited three forms from the United States: mixtus, affinis and bicornis, but Emery has shown that the first of these differs slightly from the European mixtus and had been previously described by Walsh as Formica aphidicola, and that the last is a distinct subspecies which he has called minutus. He was unable to find affinis among his American material and I have been equally unsuccessful. This form, therefore, is probably not represented on our continent. More recently

${ }^{1}$ Contributions from the Entomological Laboratory of the Bussey Institution, Harvard University, No. 30 . 

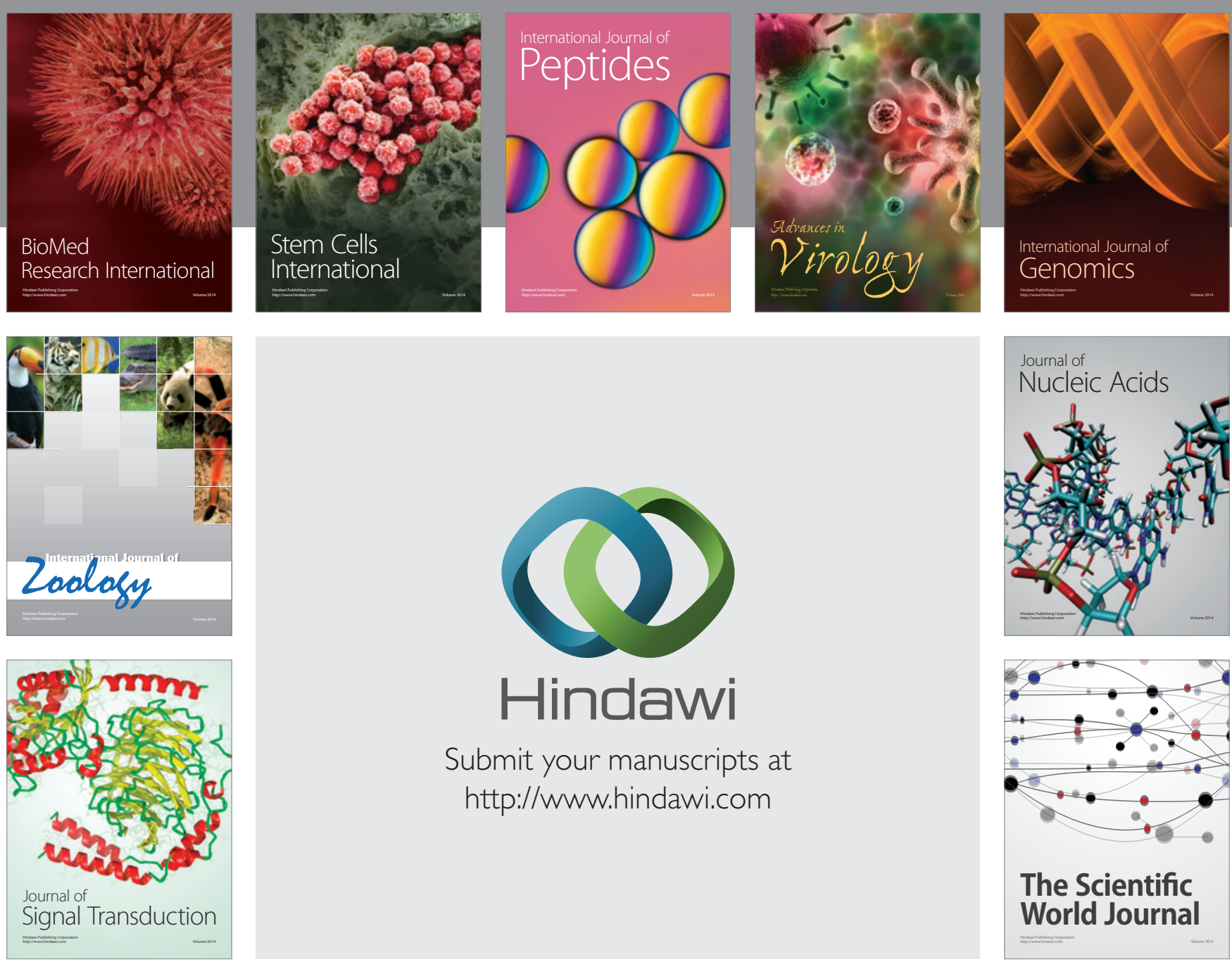

Submit your manuscripts at

http://www.hindawi.com
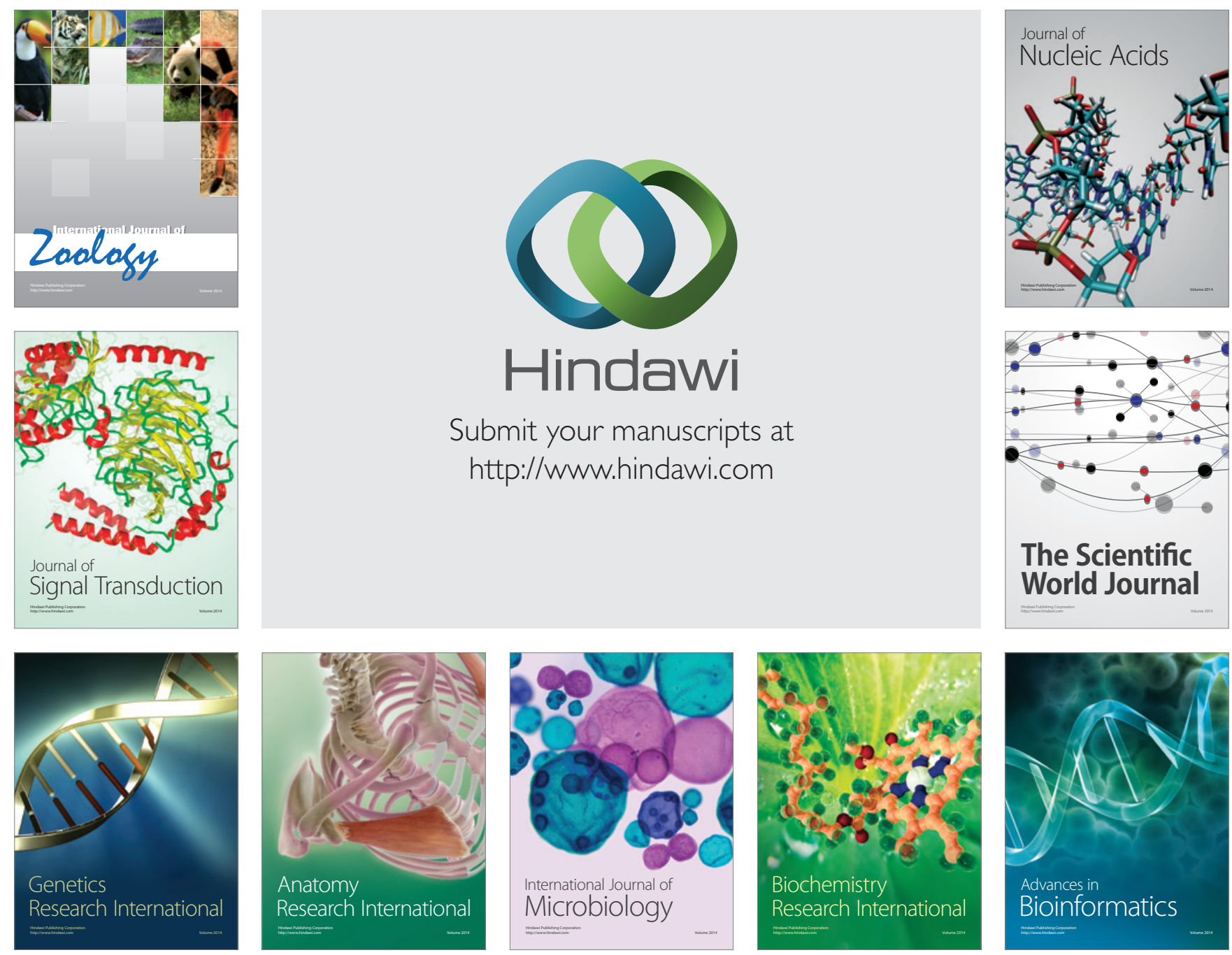

The Scientific World Journal
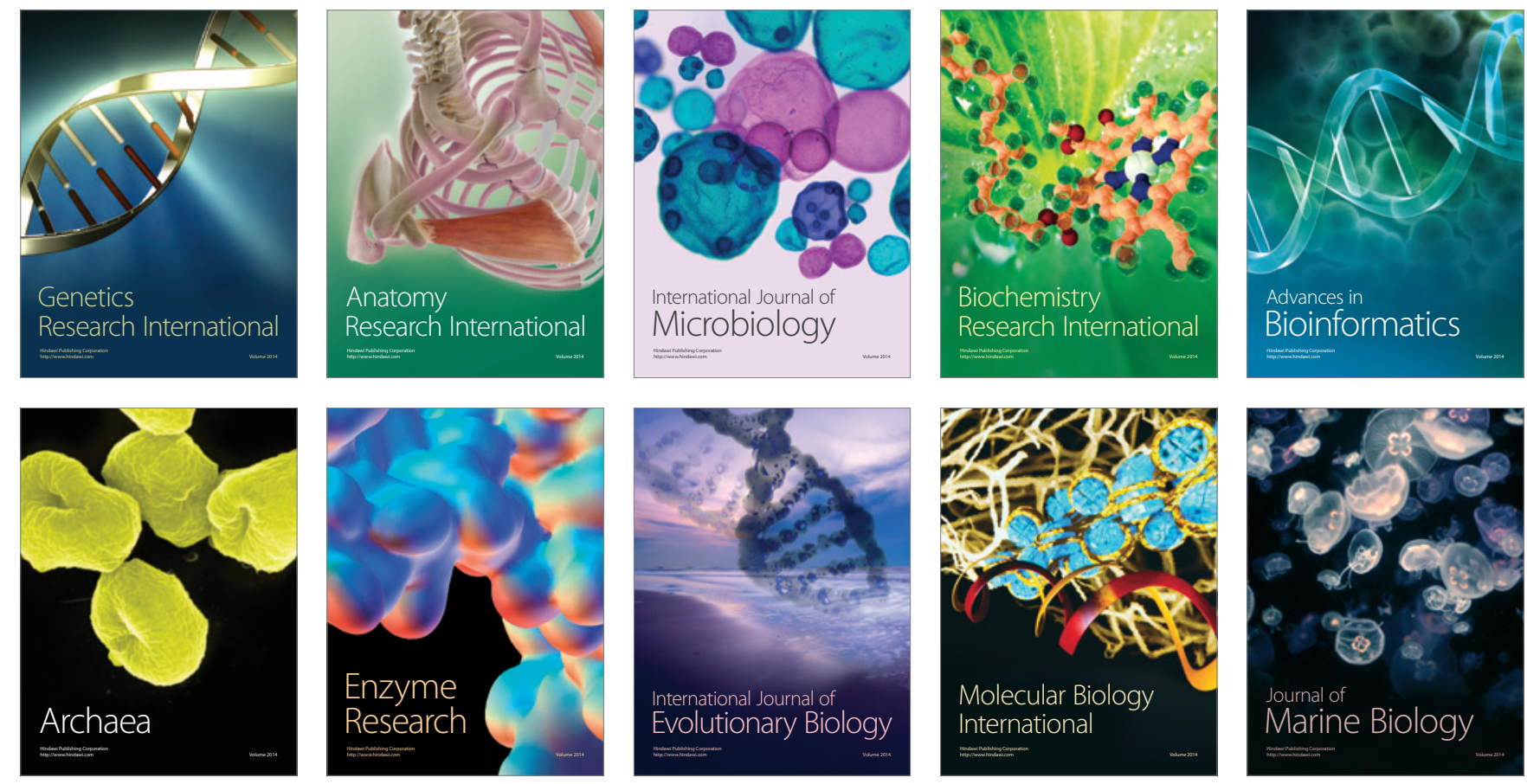